\title{
Faktor - Faktor yang Berpengaruh pada Ketepatan Waktu Internet Financial Reporting
}

\author{
Desak Made Darmayoni ${ }^{1}$ \\ Fakultas Ekonomi dan Bisnis \\ Universitas Udayana, Indonesia \\ Email desakatik.da@gmail.com
}

\author{
Anak Agung Ngurah Bagus Dwirandra ${ }^{2}$ \\ Fakultas Ekonomi dan Bisnis \\ Universitas Udayana, Indonesia
}

\begin{abstract}
ABSTRAK
Perkembangan teknologi informasi mempengaruhi perusahaan untuk menyajikan laporan keuangan melalui media internet dengan tepat waktu untuk mempermudah dalam menyebarkan informasi yang diperlukan mengenai potensi dan peluang investasi sebelum informasi tersebut kehilangan kemampuannya untuk mempengaruhi keputusan investasi. Tujuan penelitian ini adalah untuk mengetahui bukti empiris pengaruh leverage, likuiditas, profitabilitas, umur listing, dan reputasi auditor pada probabilitas ketepatan waktu Internet Financial Reporting. Penelitian ini dilakukan pada perusahaan sektor Pertambangan yang terdaftar di Bursa Efek Indonesia periode 2014 - 2017. Jumlah sampel yang diambil sebanyak 128 perusahaan, dengan menggunakan metode purposive sampling. Pengumpulan data dilakukan melalui metode observasi dan studi pustaka. Berdasarkan hasil analisis ditemukan bahwa hanya variabel profitabilitas yang berpengaruh positif dan signifikan pada probabilitas ketepatan waktu Internet Financial Reporting. Sedangkan variabel leverage, likuiditas, umur listing, dan reputasi auditor tidak berpengaruh pada probabilitas ketepatan waktu Internet Financial Reporting.
\end{abstract}

Kata Kunci: Internet Financial Reporting; Leverage; Likuiditas, Profitabilitas; Umur Listing; Reputasi Auditor.

\section{Factors That Influence Timeliness of Internet Financial Reporting}

\section{ABSTRACT}

The development of technology information are influenced company to do financial reporting through the website, to making easier to spread the required potentials information and investment opportunities. This research aims to provide empirical evidence influence of leverage, liquidity, profitability, listing age, and auditor reputation on probability timeliness of Internet Financial Reporting. The research was conducted on Mining Sector Companies listed in the Indonesian Stock Exchange in 2014 - 2017. The samples were 128 companies, with purposive sampling method. For collecting data used observation and literature. Based on the results of the analysis was found that only profitability have a positive and significant effect on the probability of timeliness of Internet Financial Reporting. While leverage, liquidity, listing age, and auditor reputation have no effect on the probability of timeliness of Internet Financial Reporting.

Keywords: Internet Financial Reporting; Leverage; Liquidity; Profitability; Listing Age; Auditor Reputation.

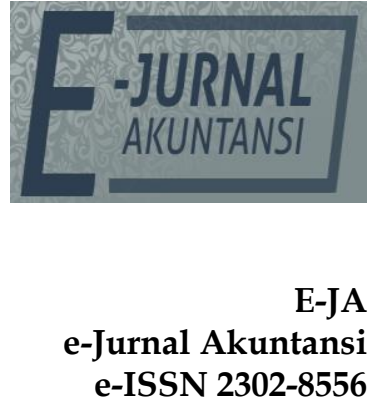

Vol. 30 No. 1

Denpasar, Januari 2020

Hal. 56-72

Artikel Masuk: 17 Juni 2019

Tanggal Diterima: 23 Agustus 2019 


\section{PENDAHULUAN}

Investor sering menggunakan internet untuk mendapatkan informasi mengenai potensi dan peluang investasi saat ini yang disebut dengan Internet Financial Reporting, yang mempermudah dan membuat informasi lebih cepat tersedia untuk public (Basuony \& Mohamed, 2014). Keumala \& Muid (2013) menyatakan bahwa Internet Financial Reporting dipandang sebagai alat dalam menyampaikan informasi lebih efektif kepada pelanggan, investor, dan pemegang saham sehingga dapat menciptakan kesan positif dan citra perusahaan.

Setiap negara memiliki kualitas Interent Financial Reporting yang berbeda yang dikarenakan oleh setiap negara tidak memiliki standar untuk perusahaan dalam melakukan pelaporan keuangan melalui website dan sifatnya masih sukarela (Dolinšek et al., 2014). Berdasarkan peraturan OJK No.8/POJK.04/2015 tentang situs web emiten atau perusahaan publik dalam pasal 2, yang menjelaskan bahwa perusahaan harus memiliki situs web yang berisi informasi atau data yang bisa dijangkau melalui sistem jaringan internet guna meningkatkan transparasi serta meningkatkan akses share holder mengenai informasi perusahaan publik yang terbaru (Almilia, 2009).

Ketepatan waktu dalam menyampaikan laporan keuangan perusahaan sangat berpengaruh pasa tingkat manfaat dan nilai dari laporan tersebut (Maryati, 2014). Ketepatan waktu dalam penyampaian laporan keuangan sesuai dengan Salinan Keputusan Ketua BAPEPAM Nomor: KEP346/BL/ 2011 tanggal 5 juli 2011 yang menyatakan bahwa laporan keuangan tahunan wajib disampaikan paling lambat pada akhir bulan ketiga setelah tanggal laporan keuangan tahunan. Dalam prakteknya masih terdapat beberapa perusahaan go public yang terlambat melakukan penyampaian laporan keuangan perusahaan yaitu pada Juni 2016, BEI menghentikan sementara perdagangan 10 saham karena terlambat menyampaikan laporan keuangan yang telah diaudit untuk 2015, pada tahun 2017 terdapat 17 saham yang mengalami suspensi, dan pada tahun 2018 terdapat 18 saham yang suspensi.

Keterlambatan penyampain laporan keuangan oleh beberapa perusahaan disebabkan oleh beberapa faktor diantaranya leverage, likuiditas, profitabilitas, umur listing, dan reputasi auditor yang digunakan (Pranata \& Pujiati, 2015). Leverage merupakan alat ukur seberapa besar perusahaan tergantung pada kreditur dalam membiayai aset perusahaan (Agboola \& Salawu, 2012). Beberapa peneliti terdahulu menemukan pengaruh leverage terhadap Internet Financial Reporting yaitu Diatmika \& Yadnyana (2017) dan Alghofur (2014),. Hal tersebut tidak sejalan dengan penelitian olehh Prasetya \& Irwandi (2016), Akbar \& Daljono (2014), Marwati (2016), serta Maharani (2017) yang menemukan leverage tidak berpengaruh pada Internet Financial Reporting.

Likuiditas merupakan tingkat kemapuan perusahaan untuk membayar kewajiban jangka pendek (Boubaker et al., 2012). Perusahaan dengan likuiditas tinggi termotivasi untuk melakukan Internet Financial Reporting karena berpengaruh pada status going concern perusahaan. Penelitian yang telah dilakukan oleh Marwati (2016) serta Insani \& Agustina (2015), menyatakan bahwa likuiditas berpengaruh terhadap Internet Financial Reporting. Penelitian oleh Prasetya \& Irwandi (2016) serta Putri \& Irwandi (2016), menyatakan bahwa likuiditas tidak berpengaruh pada Internet Financial Reporting. 
Profitabilitas merupakan kemampuan perusahaan dalam menghasilkan keuantungan(Goreti \& Lourenço, 2011). Perusahaan dengan tingkat profitabilitas tinggi dapat semakin cepat mempublikasikan laporan keuangan perusahaan. Rozak (2012), Akbar \& Daljono (2014), serta Marwati (2016), mendapatkan bahwa profitabilitas berpengeruh pada Internet Financial Reporting. Penelitian oleh Diatmika \& Yadnyana (2017), Anna (2013), Putra \& Ramantha (2015), dan Maharani (2017), menyatakan bahwa profitabilitas tidak berpengaruh pada Internet Financial Reporting.

Umur listing merupakan umur perusahaan sejak terdaftar di Bursa Efek Indonesia (Ojah \& Mokoaleli-Mokoteli, 2012). Variabel umur listing yang telah diteliti oleh Prasetya \& Irwandi (2016), Ikhsan (2017), serta Putri \& Irwandi (2016) menyatakan bahwa umur listing tidak berpengaruh terhadap Internet Financial Reporting. Penelitian oleh Hanny \& Chariri (2012) menyatakan bahwa umur listing berpengaruh positif terhadap Internet Financial Reporting dan penelitian oleh Akhirra (2013) menyatakan umur listing berpengaruh negatif terhadap pengungkapan Internet Financial Reporting.

Reputasi auditor adalah suatu sinyal positif bagi perusahaan dalam meningkatkan citra perusahaan karena perusahaan yang menggunakan jasa auditor yang bereputasi big four dianggap mampu mengahasilkan informasi keuangan yang baik dan lebih dipercayai oleh public (Abdelsalam \& Masry, 2008). Akhirra (2013) menemukan bahwa reputasi auditor berpengaruh terhadap Internet Financial Reporting. Hasil penelitian Diatmika \& Yadnyana (2017), Alghofur (2014), Putri \& Irwandi (2016) menemukan bahwa reputasi auditor tidak berpengaruh pada Internet Financial Reporting.

Hasil penelitian tentang Internet Financial Reporting masih menghasilkan temuan yang tidak konsisten sehingga perlu dilakukan pengujian lebih lanjut untuk mengetahui konsitensi temuan. Penelitian ini mengacu pada penelitian oleh Diatmika \& Yadnyana (2017) yang meneliti tentang "Pengungkapan Pelaporan Keuangan melalui Website dan Faktor-Faktor yang Memengaruhi". Penelitian ini menggunakan variable ukuran perusahaan, profitabilitas, leverage, reputasi auditor, kepemilikan publik, dan penawaran saham baru, dengan perusahaan non keuangan yang terdaftar di BEI pada tahun 2013 sebagai sampel penelitian. Hasil penelitian ini adalah ukuran perusahaan dan leverage berpengaruh positif terhadap Internet Financial Reporting.

Penelitian ini juga mengacu pada hasil penelitian Alghofur (2014), "Analisis Pengaruh Ukuran Perusahaan, Leverage, Umur Listing, dan Reputasi Auditor terhadap Penerapan Internet Financial Reporting (pada Perusahaan Property dan Real Estate yang terdaftar di BEI tahun 2010-2013)." Hasil dari penelitian ini adalahukuran perusahaan dan leverage berpengaruh positif terhadap Internet Financial Reporting.

Berdasarkan latar belakang penelitian yang diuraikan maka peneliti tertarik untuk melakukan penelitian mengenai Faktor - Faktor yang Berpengaruh pada Ketepatan Waktu Internet Financial Reporting. Adapun rumusan masalah dalam penelitian ini adalah 1) Apakah leverage berpengaruh pada probabilitas ketepatan waktu Internet Financial Reporting? 2) Apakah likuiditas berpengaruh pada probabilitas ketepatan waktu Internet Financial Reporting? 3) Apakah profitabilitas berpengaruh pada Ketepatan waktu Internet 
Financial Reporting? 4) Apakah umur listing berpengaruh pada probabilitas ketepatan waktu Internet Financial Reporting? 5) Apakah reputasi auditor berpengaruh pada probabilitas ketepatan waktu Internet Financial Repoting?.

Penelitian ini diharapkan dapat memberikan manfaat bagi pihak-pihak yang terkait seperti dapat memberikan bukti empiris dan memberikan pengetahuan dalam bidang ilmu akuntansi tentang faktor-faktor yang mempengaruhi pelaporan keuangan melalui internet atau Internet Financial Reporting (IFR) berupa leverage, likuiditas, profitabilitas, umur listing, dan reputasi auditor pada perusahaan yang terdaftar di Bursa Efek Indonesia. Teori sinyal yang berlaku ketika terkait pada pengaruh profitabilitas pada ketepatan waktu Internet Financial Reporting (IFR). Profitabilitas dapat memberikan sinyal positif kepada publik dalam menilai kemampuan perusahaan Pertambangan.

Teori Keagenan yang berlaku ketika perusahaan mampu melakukan penyampaian laporan keuangan kepada publik melalui website secara tepat waktu. Ketepatan waktu Internet Financial Reporting (IFR) dapat mengurangi terjadinya asimetri informasi antara agen dan principal karena informasi yang diperlukan melalui laporan keuangan dapat diakses dengan mudah oleh publik sebagai bahan pertimbangan investasi. Agar dapat menerapkan dan memanfaatkan praktik Internet Financial Reporting (IFR) dengan baik sehingga dapat membantu meningkatkan komunikasi dengan berbagai pihak, khususnya investor dan pemegang saham.

Penelitian ini dapat menjadi bahan kajian untuk mengetahui pengaruh pelaporan keuangan melalui website perusahaan baik secara internal maupun secara eksternal. Sebagai bahan referensi untuk menciptakan image perusahaan yang lebih baik. Dapat memberikan informasi untuk membantu pengambilan keputusan dalam menilai ketepatan waktu pelaporan informasi keuangan perusahaan dengan memanfaatkan teknologi internet, serta mempermudah dalam mendapatkan informasi yang diperlukan investor dalam keputusan investasi. Sebagai sumber referensi dan memberikan sumbangan konseptual bagi peneliti yang akan melakukan penelitian yang terkait dalam rangka mengembangkan ilmu pengetahuan serta dapat memberikan bukti empiris tentang faktor-faktor yang berpengaruh pada ketepatan waktu Internet Financial Reporting.

Teori Keagenan (Agency Theory), menggambarkan hubungan yang terjadi antara pihak agen dengan prinsipal yang menyebabkan munculnya asimetri informasi dan akhirnya berujung dengan konflik. Teori keagenan membuat suatu model kontraktual antara dua atau lebih orang (pihak) dimana salah satu pihak disebut agen dan pihak lain disebut prinsipal. Manajemen perusahaan merupakan agen dan pemegang saham merupakan prinsipal yang berkepentingan atas kepemilikannya terhadap perusahaan.

Teori keagenan menyatakan bahwa dalam asimetri informasi, manajemen dapat memilih keputusan yang memaksimalkan kepentingannya. Keputusan ini berbeda dengan keputusan yang dibutuhkan untuk memaksimalkan kepentingan pemegang saham.

Teori sinyal didasarkan pada asumsi bahwa informasi yang diterima oleh masing-masing pihak tidaksama. Teori sinyal memusatkan perhatian pada pengaruh informasi terhadap perubahan perilaku pemakai informasi tersebut. 
Perusahaan perlu memberikan sinyal kepada pengguna laporan keuangan berupa informasi bagi pihak-pihak yang berkepentingan melalui penerbitan laporan keuangan. Sinyal ini berupa informasi mengenai apa yang sudah dilakukan oleh manajemen untuk merealisasikan keinginan pemilik. Sebuah informasi dikatakan bermanfaat apabila informasi tersebut benar adanya dan seakan-akan digunakan dalam pengambilan keputusan oleh pihak-pihak lain. Informasi dapat berupa promosi atau informasi lain yang menyatakan bahwa perusahaan tersebut lebih baik daripada perusahaan lain.

Teori Sinyal dapat digunakan untuk memprediksi kualitas pelaporan sukarela, yaitu dengan menggunakan media internet maka dapat digunakan untuk meningkatkan kualitas pelaporan keuangan. Melalui website, perusahaan memberikan sinyal kepada pihak yang berkepentingan dengan keadaan perusahaan saat ini dan prospek perusahaan di masa mendatang. Praktik Internet Financial Reporting tidak dapat dipisahkan dari teori sinyal (signalling theory). Teori sinyal menyatakan bahwa dorongan perusahaan untuk memberikan informasi dikarenakan terdapat asimetri informasi antara manajer perusahaan dan pihak eksternal karena manajer perusahaan mengetahui segala sesuatu mengenai perusahaan dan prospek perusahaan di masa depan yang tentu saja lebih banyak dibandingkan dengan pihak eksternal.

Perusahaan dapat meningkatkan nilai perusahaan dengan mengurangi asimetri informasi. Salah satu cara untuk mengurangi asimetri informasi adalah dengan memberikan sinyal pada pihak luar, contohnya informasi keuangan yang positif dapat dipercaya akan mengurangi ketidakpastian tentang prospek perusahaan di masa yang akan datang sehingga dapat meningkatkan kredibilitas dan kesuksesan perusahaan. Internet Financial Reporting membantu perusahaan dalam menyebarluaskan informasi mengenai keunggulan-keunggulan perusahaan yang merupakan sinyal positif perusahaan untuk menarik investor. Hal ini berarti, Internet Financial Reporting merupakan sarana untuk mengkomunikasikan sinyal positif perusahaan kepada publik, terutama investor

Kualitas Internet Financial Reporting (IFR) dapat dinilai oleh empat komponen yaitu Isi/Content, yaitu meliputi komponen laporan keuangan seperti laporan neraca, laba rugi, arus kas, perubahan posisi keuangan serta laporan keberlanjutan perusahaan. Informasi keuangan yang diungkapkan dalam bentuk html memiliki skor yang lebih tinggi dibandingkan dengan format pdf, karena dapat mengakses laporan keuangan lebih cepat.

Ketepatan waktu, yaitu ketika website perusahaan sering melakukan pembaharuan serta dapat menyajikan informasi terkini dengan tepat waktu. Pemanfaatan teknologi, yaitu terkait dengan pemanfaatan teknologi yang tidak dapat disediakan oleh media laporan cetak serta penggunaan media teknologi multimedia, analisis tools, fitur-fitur lanjutan. User Support, indeks website perusahaan semakin tinggi jika perusahaan mengimplementasikan secara optimal semua sarana dalam website perusahaan.

Ketepatan waktu adalah hal penting dalam pelaporan informasi keuangan karena mendapat perhatian dari regulator. Ketepatan waktu berperan penting dalam menentukan kegunaan Internet Financial Reporting. Hal ini karena kegunaan dari informasi erat kaitannya dengan waktu pengungkapan kepada 
stakeholder dalam mengintegrasikan secara efektif informasi yang diungkapkan dalam rangka pengambilan keputusan

Penelitian ini memberikan bukti bahwa teori sinyal berlaku keteka terkait dengan pengaruh profitabilitas pada ketepatan waktu Internet Financial Reporting dan teori keagenan berlaku ketika perusahaan mampu melakukan penyampaian laporan keuangan kepada public melalui website secara tepat waktu (Oyelere et al., 2003). Bagi perusahaan penelitian ini dapat menerapkan dan memanfaatkan praktik Internet Financial Reporting dengan baik sehingga dapat membantu meningkatkan komunikasi dengan publik dan mampu meningkatkan citra perusahaan (Aly et al., 2010).

Teori Keagenan (Agency Theory), menggambarkan hubungan yang terjadi antara pihak agen dengan principal yang menyebabkan munculnya asimetri informasi dan akhirnya berujung dengan konflik (Debreceny et al., 2002). Dalam Kusrinanti (2012), ada tiga jenis agency relationship yaitu 1) Bonus plan hypothesis yang menjelaskan hubungna keagenan dapat mengarah pada kondisi asimetri informasi antara manjemen dengan pemegang saham. 2) Debt/equity hyphothesis yang menjelaskan terdapat hubungan antara leverage dan pilihan prosedur akuntansi. 3) Political cost hyphothesis yang menjelaskan perusahaan besar cenderung mendapat tekanan public yang diatasi dengan usaha perusahaan untuk mempublikasikan laporan keuangan tepat waktu.

Teori sinyal didasarkan pada asumsi bahwa informasi yang diterima oleh masing-masing pihak tidaksama. Teori sinyal digunakan untuk memprediksi kualitas laporan sukarela melaui website sehingga perusahaan mampu memberikan sinyal positif untuk pihak yang berkepentingan dengan keadaan perusahaan saat ini dan prospek perusahaan dimasa mendatang.

Suatu cara yang dilakukan perusahaan untuk mencantumkan laporan keuangan melalui website yang dimiliki perusahaan adalah pengertian dari Internet Financial Reporting (Marwati, 2016). Kualitas Internet Financial Reporting dapat dinilai dari empat komponen yang meliputi isi/ content, ketepatan waktu, pemanfaatan teknologi dan user support. Ketepatan waktu memiliki peran penting dalam menentukan kegunaan Internet Financial Reporting, karena erat kaitannya dengan waktu pengungkapan kepada stakeholder dalam mengintegrasikan secara efektif informasi yang diungkapkan dalam rangka pengambilan keputusan

Kemampuan perusahaan dalam memenuhi hutang dengan modal/ ekuitas yang dimiliki disebut Leverage. Leverage mengacu pada seberapa jauh perusahaan bergantung pada kreditur dalam membiayai aset perusahaan. Menurut Alali \& Romero (2012) perusahaan yang memiliki leverage yang tinggi dapat menyebabkan badnews bagi perusahaan, sehingga perusahaan cenderung menghindari pelaporan informasi keuangan termasuk dalam website perusahaan, karena dapar mempengaruhi prospek perusahaan dimasa mendatang. Beberapa penelitian yang menemukan pengaruh leverage pada ketepatan waktu Internet Financial Reporting adalah penelitian oleh Alghofur (2014) dan Anna (2013).

$\mathrm{H}_{1}$ : Leverage berpengaruh negatif pada probabilitas ketepatan waktu Internet Financial Reporting. 
Likuiditas merupakan kemampuan perusahaan melunasi kewajiban jangka pendek. Perusahaan semakin likuid ditandai dengan semakin tinggi kemampuan perusahaan melunasi hutang jangka pendeknya dan cenderung untuk mempublikasikan laporan keuangan audited tepat waktu. Informasi tentang tingkat likuiditas perusahaan dapat membuat investor yakin untuk menanamkan modal pada perusahaan yang bersangkutan. Beberapa penelitian yang menemukan pengaruh positif likuiditas pada ketepatan waktu Internet Financial Reporting yaitu penelitian oleh Marwati (2016) serta Insani \& Agustina (2015).

$\mathrm{H}_{2}$ : Likuiditas berpengaruh positif pada probabilitas ketepatan waktu Internet Financial Reporting.

Profitabilitas merupakan kemampuan perusahaan dalam menghasilkan keuantungan. Perusahaan dengan profitabilitas tinggi cenderung mengungkapkan aktivitas perusahaan semakin rinci dan mempublikasikan laporan keuangan semakin cepat sebagai goodnews kepada publik. Rozak (2012), Akbar \& Daljono (2014), serta Marwati (2016) menemukan bahwa profitabilitas berpengaruh positif pada Internet Financial Reporting.

$\mathrm{H}_{3}$ : Profitabilitas berpengaruh positif pada probabilitas ketepatan waktu Internet

Financial Reporting.

Umur listing merupakan umur perusahaan sejak terdaftar di Bursa efek Indonesia. Perusahaan yang memiliki umur listing yang lebih lama dapat meningkatkan praktek Internet Financial Reporting dari waktu ke waktu. Semakin lama perusahaan terdaftar, maka semakin mampu menyediakan publisitas informasi keuangan perusahaan dengan aksesibilitas yang tinggi. Penelitian yang dilakukan oleh Hanny \& Chariri (2012), dan Akhirra (2013) menunjukkan umur listing berpengaruh pada Internet Financial Reporting.

$\mathrm{H}_{4}$ : Umur listing berpengaruh positif pada probabilitas ketepatan waktu Internet Financial Reporting.

Reputasi auditor dari Kantor Akuntan Publik yang berkulifikasi memberikan keyakinan kepada investor tentang laporan keuangan yang diaudit (Anggraini, 2012). Perusahaan cenderung menggunakan KAP yang berafiliasi dengan Big Four yaitu Ernst \& Young, Deloitte Touche Tohmatsu, KPMG, serta Price Waterhouse Copper. Audit yang dilakukan oleh KAP yang termasuk dalam big four merupakan jasa audit yang berintegritas dan berkualitas sehingga menimbulkan potensi sebagai sinyal untuk menarik investor. Beberapa penelitian yang telah membuktikan pengaruh positif reputasi auditor pada Internet Financial Reporting adalah penelitian oleh Akhirra (2013) dan Marwati (2016).

$\mathrm{H}_{5}$ : Reputasi auditor berpengaruh positif pada probabilitas ketepatan waktu Internet Financial Reporting.

\section{METODE PENELITIAN}

Penelitian ini menggunakan pendekatan kuantitatif (penelitian dengan memperoleh data yang berbentuk angka). Lokasi penelitian dilakukan pada Perusahaan Pertambangan yang terdaftar di Bursa Efek Indonesia. Objek penelitian ini adalah ketepatan waktu Internet Financial Reporting, leverage, likuiditas, profitabilitas, umur listing, dan reputasi auditor pada Perusahaan Pertambangan yang terdaftar di Bursa Efek Indonesia pada tahun 2014-2017. 
Ketepatan waktu Internet Financial Reporting diukur dengan variabel dummy yaitu angka "1" untuk perusahaan yang melakukan Internet Financial Reporting dan melaporkan informasi keuangan di internet $\leq 90$ hari dan apabila perusahaan sampel yang tidak melakukan Internet Financial Reporting dan melaporkan informasi keuangan $>90$ hari diberi angka " 0 ". Pengukuran ini telah dilakukan oleh Alghofur (2014).

Tingkat leverage diukur dengan menggunakan rasio Debt to Equity Ratio (DER), yang dihitung dengan total hutang dibagi dengan total ekuitas. Dari hasil pengukuran, apabila rasio tinggi, maka pendanaan dengan utang semakin banyak. Jika perusahaan yang baik memiliki komposisi modal yang lebih besar daripada hutang.

Leverage $=\frac{\text { total hutang }}{\text { total modal }}$

Likuiditas adalah suatu indicator kemampuan perusahaan untuk membayar semua kewajiban keuangan jangka pendek pada saat jatuh tempo dengan menggunakan aset lancar yang tersedia. Rasio likuiditas merupakan suatu perbandingan antara total aset lancar dengan total utang lancar.

Current Ratio $=\frac{\text { Aset lancar }}{\text { Utang Lancar }}$

Profitabilitas merupakan suatu aspek penting yang dapat dijadikan acuan oleh investor atau pemilik untuk menilai kinerja manajemen dalam mengelola suatu perusahaan. Pada penelitian ini, profitabilitas diukur dengan Return on Asset (ROA). Semakin besar rasio profitabilitas maka perputaran aset lebih cepat dan dapat meraih laba.

ROA $=\frac{\text { Laba bersihsetelah pajak }}{\text { Rata-rata totalaset }}$

Umur listing dalam penelitian ini diukur dengan menghitung selisih antara tahun pengamatan penelitian dengan tahun First Issue atau Initial Public Offering (IPO). Semakin panjang umur perusahaan, memberikan pengungkapan informasi keuangan yang lebih luas dibanding perusahaan lain yang umurnya lebih pendek dengan alasan perusahaan tersebut memiliki pengalaman lebih dalam pengungkapan laporan tahunan (Maharani, 2017)

Umur Listing = Umur pengamatan - Tahun first issue (IPO)

Penggunaan Kantor Akuntan Publik (KAP) yang bereputasi merupakan salah satu sinyal positif bagi perusahaan karena perusahaan dianggap memiliki informasi yang lebih lengkap dan melaporkan informasi keuangan secara lebih transparan. Reputasi auditor diukur dengan menggunakan variabel dummy dengan melihat apakah KAP tersebut berafiliasi dengan KAP big four. Pemberian kode " 1 " untuk KAP big four, dan kode " 0 " untuk KAP non big four.

Populasi dalam penelitian ini adalah seluruh perusahaan sektor Pertambangan yang terdaftar di BEI pada tahun 2014 - 2017. Purposive sampling, dengan kriteria sebagai berikut ; 1) Perusahaan pertambangan yang terdaftar secara berturut-turut pada tahun 2014 - 2017, 2) Perusahaan pertambangan yang menerapkan Internet Financial Reporting, 3) Perusahaan pertambangan yang mempublikasikan laporan keuangan lengkap yang telah diaudit selama 3 tahun pengamatan (2014 - 2017). Metode pengumpulan data yang digunakan dalam penelitian ini adalah metode observasi pada website perusahaan yang dijadikan 
sampel dan dengan studi pustaka yaitu pengumpulan data sebagai landasan teori serta penelitian terdahulu.

Teknik analisis data yang digunakan dalam penelitian ini analisis multivariate dengan menggunakan regresi logistik biner. Metode uji regresi logistik yang digunakan adalah metode simultan (enter). Model regresi logistic biner yang digunakan dalam penelitian ini adalah sebagai berikut :

$\operatorname{Ln} \frac{I F R}{1-I F R}=\alpha+\beta$ LEV $+\beta$ LIKUID $+\beta$ PROF $+\beta$ UMUR $+\beta$ AUD $+\varepsilon$

Keterangan :

\begin{tabular}{|c|c|c|}
\hline $\operatorname{Ln} \frac{I F R}{1-I F R}$ & & Dummy variable, nilai 1 apabila perusahaan tepat waktu \\
\hline & & $\begin{array}{l}\text { melakukan IFR dan nilai } 0 \text { apabila perusahaan tidak tepat } \\
\text { waktu melakukan IFR. }\end{array}$ \\
\hline a & & konstanta \\
\hline$\beta \mathrm{LEV}$ & & Rasio leverage perusahaan (DER) \\
\hline$\beta$ LIKUID & & Rasio likuiditas (CR) \\
\hline$\beta P R O F$ & & Rasio ProfitabilitaHASILs (ROA) \\
\hline$\beta U M U R$ & & Umur listing \\
\hline$\beta A U D$ & & $\begin{array}{l}\text { Dummy variable untuk reputasi auditor, nilai } 1 \text { untuk KAP } \\
\text { yang termasuk big four dan nilai } 0 \text { untuk KAP yang termasuk } \\
\text { non big four } \\
\text { error }\end{array}$ \\
\hline
\end{tabular}

\section{HASIL DAN PEMBAHASAN}

Berdasarkan metode purposive sampling, diperoleh jumlah sampel amatan yang memenuhi kriteria selama tahun 2014-2017 adalah sebanyak 128 perusahaan, yang ditunjukkan oleh Tabel 1.

Tabel 1. Hasil Seleksi Sampel

\begin{tabular}{llc}
\hline No. & Keterangan & $\begin{array}{c}\text { Jumlah } \\
\text { Perusahaan }\end{array}$ \\
\hline 1 & $\begin{array}{l}\text { Perusahaan pertambangan yang terdaftar di Bursa Efek } \\
\text { Indonesia tahun 2014-2017 }\end{array}$ & 41 \\
2 & $\begin{array}{l}\text { Perusahaan pertambangan yang tidak terdaftar secara } \\
\text { berturut-turut pada tahun 2014-2017 }\end{array}$ & $(4)$ \\
3 & $\begin{array}{l}\text { Perusahaan pertambangan yang tidak mempublikasikan } \\
\text { LK selama 4 tahun penelitian }\end{array}$ & $(2)$ \\
$4 \quad \begin{array}{l}\text { Perusahaan pertambangan yang tidak memiliki laporan } \\
\text { auditor independen selama 3 tahun penelitian }\end{array}$ & - \\
$\quad \begin{array}{l}\text { Perusahaan pertambangan yang mengalami suspense } \\
\text { selama 4 tahun penelitian }\end{array}$ & $(3)$ \\
Jumlah Sampel Perusahaan & 32 \\
Jumlah observasi yang memenuhi kriteria periode 2014 -2017 & 128
\end{tabular}

Sumber : Data Penelitian, 2018

Statistik deskriptif disajikan untuk memberikan informasi mengenai karakteristik variabel-variabel penelitian, yaitu jumlah sampel, nilai maksimum, nilai minimum, nilai rata-rata, dan standar deviasi. Hasil statistik deskriptif menunjukkan nilai rata-rata ketepatan waktu IFR sebesar 0,59 dengan standar deviasi sebesar 0,493. Hal ini menunjukkan bahwa dari 128 sampel penelitian 
terdapat 75 sampel tepat waktu melakukan IFR (kode 1), sedangkan sisanya sejumlah 53 sampel tidak tepat waktu melakukan IFR (kode 0).

Tabel 2. Hasil Uji Statistik Deskriptif

\begin{tabular}{llrrrr}
\hline & N & Minimum & Maximum & Mean & Std. Deviation \\
\hline IFR & 128 & 0 & 1 & 0,59 & 0,493 \\
LEV & 128 & $-5,567$ & 10,206 & 1,4361 & 2,017931 \\
LIKUID & 128 & 0,020 & 20,170 & 2,1037 & 2,45878 \\
PROF & 128 & $-0,587$ & 1,557 & 0,0480 & 0,195182 \\
UMUR & 128 & 1 & 27 & 12,41 & 7,535 \\
AUD & 128 & 0 & 1 & 0,55 & 0,500 \\
Valid N (listwise) & 128 & & & & \\
\hline
\end{tabular}

Sumber : Data Penelitian, 2018

Variabel leverage berjumlah 128 menunjukkan nilai rata-rata leverage sebesar sebesar 1,4361 dengan standar deviasi sebesar 2,017931. Hal ini berarti untuk setiap Rp.100 aset yang dimiliki oleh perusahaan, Rp. 1,4361 nya dibiayai dari utang. Nilai maksimum sebesar 10,206 yang dimiliki oleh Perusahaan Golden Energy Mines Tbk. dan nilai minimum sebesar -5,567 yang dimiliki oleh Perusahaan Bumi Resources Tbk.

Pada variabel likuiditas menunjukkan nilai rata-rata likuiditas sebesar 2,1037 dengan standar deviasi sebesar 2,45878. Hal ini berarti untuk setiap Rp.100 utang lancar dijamin atau ditanggung oleh Rp. 2,1037 aset lancar. Nilai maksimum sebesar 20,170 yang dimiliki oleh Perusahaan Central Omega Resources Tbk. dan nilai minimum sebesar 0,020 yang dimiliki oleh Perusahaan Central Omega Resources Tbk.

Variabel profitabilitas yang berjumlah 128 menunjukkan nilai rata-rata profitabilitas sebesar 0,0480 dengan standar deviasi sebesar 0,95182. Hal ini berarti setiap Rp.100 aset perusahaan, sebesar Rp.0,0480 laba yang dihasilkan perusahaan setelah bunga dan pajak. Nilai maksimum sebesar 1,557 yang dimiliki oleh Perusahaan Delta Dunia Makmur Tbk. dan nilai minimum sebesar -0,587 yang dimiliki oleh Perusahaan Mitra Investindo Tbk.

Variabel umur listing menunjukkan nilai rata-rata umur listing sebesar 12,41 dengan standar deviasi sebesar 7,535. Nilai maksimum sebesar 27 yang dimiliki oleh Perusahaan Vale Indonesia Tbk. dan nilai minimum sebesar 1 yang dimiliki oleh Perusahaan Mitrabara Adiperdana Tbk.

Variabel reputasi auditor menunjukkan nilai rata-rata reputasi auditor sebesar 0,55 dengan standar deviasi sebesar 0,500. Hal ini menunjukkan bahwa dari 128 sampel penelitian terdapat 70 sampel termasuk dalam KAP big four (kode 1), sedangkan sisanya sejumlah 58 sampel tidak termasuk dalam KAP big four (kode 0).

Selanjutnya dilakukan uji regresi logistik biner yang meliputi : menilai kelayakan model regresi dengan uji Hosmer dan Lemeshow, menilai keseluruhan model (Overall model fit), Koefisien determinasi (Nagelkerke $R$ Square), Matrik Klasifikasi, dan pengujian simultan (Obnibus Test of Model Coefficient). Uji Hosmer dan Lemeshow menunjukkan bahwa nilai Chi-square sebesar 13,638 dengan signifikasi sebesar 0,092, diperoleh nilai signifikansi yang lebih besar dari 0,05 $(0,092>0,05)$, yang berarti model mampu memprediksi nilai observasinya atau model yang dihipotesiskan cocok dengan data observasinya. 
Menilai keseluruhan model (Overall model fit) menjelaskan nilai -2LL awal adalah sebesar 172,919 dan nilai akhir mengalami penurunan menjadi 161,687. Penurunan nilai log likehood (-2LL), menunjukkan bahwa model regresi yang diuji adalah baik atau dengan kata lain model yang dihipotesiskan fit dengan data. Nilai Nagelkerke $R$ Square adalah sebesar 0,113 yang berarti bahwa variabilitas variabel dependen yang dapat dijelaskan oleh variabel independen adalah sebesar $11,3 \%$, sedangkan sisanya sebesar $88,7 \%$ dijelaskan oleh faktor variabelvariabel lain diluar model penelitian.

Hasil pengujian matriks klasifikasi menjelaskan kekuatan prediksi dari model regresi untuk memprediksi kemungkinan perusahaan tidak tepat waktu melakukan Internet Financial Reporting sebesar 32,7\%. Kekuatan prediksi kemungkinan tepat waktu melakukan Internet Financial Reporting adalah sebesar 92,1\%. Hasil Omnibus Test of Model Coefficient menunjukkan nilai $\mathrm{X}_{2}=11,232>\mathrm{X}_{2}$ tabel pada df 5 (jumlah variabel independen) yaitu, 11,070 atau dengan sign]ifikansi sebesar $0,047(<0,05)$, sehingga menolak $\mathrm{H}_{\mathrm{o}}$, yang menunjukkan bahwa penambahan variabel independen dapat memberikan pengaruh nyata terhadap model, atau dengan kata lain model dinyatakan FIT.

Nilai konstanta sebesar 0,676 berarti bahwa apabila variabel bebas bernilai konstan, maka kecenderungan perusahaan tepat waktu melakukan IFR semakin besar atau naik. Koefisien regresi variabel leverage sebesar -0,099 yang memiliki arti bahwa setiap peningkatan satu satuan leverage, peluang perusahaan tepat waktu melakukan Internet Financial Reporting semakin kecil dengan asumsi variabel lainnya konstan. Koefisien regresi variabel likuiditas sebesar -0,101 yang memiliki arti bahwa setiap peningkatan satu satuan likuiditas, peluang perusahaan tepat waktu melakukan Internet Financial Reporting semakin kecil dengan asumsi variabel lainnya konstan. Koefisien regresi variabel profitabilitas sebesar 3,593 yang memiliki arti bahwa setiap peningkatan satu satuan profitabilitas, peluang perusahaan tepat waktu melakukan Internet Financial Reporting semakin besar dengan asumsi variabel lainnya konstan.

Tabel 3. Hasil Uji Regresi Logistik

\begin{tabular}{lcccl}
\hline \multicolumn{1}{c}{ Variabel } & $\mathrm{B}$ & Wald & Sig. & \multicolumn{1}{c}{ Keterangan } \\
\hline Leverage & $-0,099$ & 1,103 & 0,294 & Tidak signifikan \\
Likuiditas & $-0,010$ & 1,213 & 0,271 & Tidak signifikan \\
Profitabilitas & 3,593 & 4,450 & 0,035 & Signifikan \\
Umur Listing & 0.009 & 0,112 & 0,738 & Tidak signifikan \\
Reputasi Auditor(1) & $-0,383$ & 0,962 & 0,327 & Tidak signifikan \\
Constant & 0,678 & & & \\
\hline
\end{tabular}

Sumber : Data Penelitian, 2018

Koefisien regresi variabel umur listing sebesar 0,009 yang memiliki arti bahwa setiap peningkatan satu satuan umur listing, peluang perusahaan tepat waktu melakukan Internet Financial Reporting semakin besar dengan asumsi variabel lainnya konstan. Koefisien regresi variabel reputasi sebesar -0,383 yang memiliki arti bahwa setiap peningkatan satu satuan reputasi auditor, peluang perusahaan tepat waktu melakukan Internet Financial Reporting semakin kecil dengan asumsi variabel lainnya konstan. 
Tabel 3 menunjukkan bahwa koefisien regresi leverage negatif sebesar 0,099 dengan tingkat signifikansi 0,294 yang lebih besar dari a (5\%) yang tidak sesuai dengan hipotesis yang diharapkan, sehingga $\mathrm{H}_{1}$ ditolak. Variabel leverage memiliki nilai signifikansi lebih besar dari 0,05 yang berarti bahwa leverage tidak berpengaruh signifikan pada probabilitas ketepatan waktu Internet Financial Reporting, yang berarti semakin tinggi leverage maka kecenderungan perusahaan melakukan Internet Financial Reporting semakin rendah.

Menurut Prasetya \& Irwandi (2016) para investor lebih menyukai perusahaan yang mempunyai rasio leverage rendah karena akan lebih memenuhi prinsip akuntansi going concern atas pengembalian investasi. Arah negatif koefisien regresi leverage dapat dijelaskan melalui kondisi data perusahaan sektor Pertambangan selama periode pengamatan tahun 2014 - 2017.

Tabel 3 menunjukkan bahwa koefisien regresi likuiditas sebesar 0,101 dengan tingkat signifikansi 0,271 yang lebih besar dari a (5\%) yang tidak sesuai dengan hipotesis yang diharapkan, sehingga $\mathrm{H}_{2}$ ditolak. Variabel likuiditas memiliki nilai signifikansi lebih besar dari 0,05 yang menunjukkan bahwa likuiditas tidak berpengaruh signifikan pada probabilitas ketepatan waktu Internet Financial Reporting, yang berarti tingkat likuiditas tidak berpengaruh pada ketepatan waktu Internet Financial Reporting.

Penelitian ini mendukung penelitian terdahulu oleh Prasetya \& Irwandi (2016), serta Putri \& Irwandi (2016), yang menyatakan bahwa likuiditas tidak berpengaruh terhadap Internet Financial Reporting. Namun penelitian ini tidak sesuai dengan hasil penelitian terdahulu oleh Marwati (2016), serta Insani \& Agustina (2015), yang menyatakan bahwa likuiditas berpengaruh terhadap Internet Financial Reporting.

Tabel 3 menunjukkan bahwa koefisien regresi profitabilitas sebesar 3,593 dengan tingkat signifikansi 0,035 yang lebih kecil dari a (5\%) yang sesuai dengan hipotesis yang diharapkan, sehingga $\mathrm{H}_{3}$ diterima. Variabel profitabilitas memiliki nilai signifikansi lebih kecil dari 0,05 yang menunjukkan bahwa profitabilitas berpengaruh positif dan signifikan pada probabilitas ketepatan waktu Internet Financial Reporting, yang berarti semakin tinggi profitabilitas maka kecenderungan perusahaan melakukan Internet Financial Reporting semakin baik. Perusahaan dengan profitabilitas tinggi cenderung untuk mengungkapkan lebih rinci mengenai aktivitas perusahaan dan mengungkapkan laporan keuangannya secepat mungkin untuk menyebarkan good news kepada publik yang bertujuan menarik minat investor.

Penelitian ini mendukung penelitian terdahulu oleh Rozak (2012), Akbar \& Daljono (2014), serta Marwati (2016), yang menemukan bahwa profitabilitas berpengaruh terhadap Internet Financial Reporting. Tingginya tingkat profitabilitas menandakan bahwa perusahaan mampu untuk melunasi kewajibannya yang nantinya berdampak pada ketepatan waktu pelaporan keuangan.

Hasil pengujian dengan regresi logistik menunjukkan bahwa koefisien regresi umur listing negatif sebesar 0,009 dengan tingkat signifikansi 0,738 yang lebih besar dari a (5\%) yang tidak sesuai dengan hipotesis yang diharapkan, sehingga $\mathrm{H}_{4}$ ditolak. Variabel umur listing memiliki nilai signifikansi lebih besar dari 0,05 yang menunjukkan bahwa umur listing tidak berpengaruh signifikan 
pada probabilitas ketepatan waktu Internet Financial Reporting, yang berarti bahwa umur listing perusahaan tidak menjadi tolak ukur untuk menentukan kemampuan perusahaan untuk tepat waktu melakukan Internet Financial Reporting. Menurut Prasetya \& Irwandi (2016), umur listing tidak berpengaruh terhadap Internet Financial Reporting yang berarti bahwa perusahaan yang memiliki umur listing lebih lama tidak menjadi jaminan bahwa perusahaan tersebut memiliki sumber daya manusia yang kompeten dalam hal teknologi untuk melakukan Internet Financial Reporting.

Hasil pengujian dengan regresi logistik menunjukkan bahwa koefisien regresi reputasi auditor negatif sebesar 0,383 dengan tingkat signifikansi 0,327 yang lebih besar dari (5\%), yang tidak sesuai dengan hipotesis yang diharapkan, sehingga $\mathrm{H}_{5}$ ditolak. Variabel reputasi auditor memiliki nilai signifikansi lebih besar dari 0,05 yang menunjukkan bahwa reputasi auditor tidak berpengaruh pada probabilitas ketepatan waktu Internet Financial Reporting.

Hasil penelitian ini sejalan dengan penelitian terdahulu oleh Diatmika \& Yadnyana (2017), Alghofur (2014), Akbar \& Daljono (2014), serta Putri \& Irwandi (2016) yang tidak menemukan adanya pengaruh reputasi auditor terhadap Internet Financial Reporting. Menurut Diatmika \& Yadnyana (2017), reputasi auditor tidak memiliki pengaruh terhadap pengungkapan pelaporan keuangan melalui website. Hasil ini tersebut dikarenakan saat ini telah banyak KAP yang tidak memiliki afiliasi dengan KAP big four namun memiliki kinerja yang setara dengan KAP big four. Dengan banyaknya KAP yang memiliki kualitas kinerja yang baik maka perusahaan tidak lagi memperhatikan apakah mereka diaudit oleh KAP big four dalam melakukan praktik pelaporan berbasis website (Akbar \& Daljono, 2014).

Hasil riset ini menunjukan bahwa tidak semua perusahaan sampel penelitian tepat waktu melakukan pelaporan Internet Financial Reporting (IFR) via internet. Terdapat bukti empiris yang diperoleh melalui penelitian ini terkait hasil olah data statistik pada perusahaan sektor Pertambangan periode 20142017, yang menunjukkan tingkat profitabilitas berpengaruh positif dan signifikan pada probabilitas ketepatan waktu Internet Financial Reporting (IFR).

Pada hasil riset ini hanya variabel profitabilitas yang mampu menjelaskan teori sinyal yang mampu memberikan tambahan informasi bagi pasar sehingga dapat meningkatkan kepercayaan dan menarik lebih banyak minat investor untuk melakukan investasi pada perusahaan. Perusahaan yang mempunyai tingkat profitabilitas yang tinggi cenderung untuk mengungkapkan informasi keuangan secepat mungkin kepada publik. Sesuai dengan teori keagenan, masih terdapat asimetri informasi antara agen dan prinsipal yang ditunjukkan dengan masih adanya perusahaan yang tidak tepat waktu melakukan Internet Financial Reporting dan berpengaruh pada perilaku pasar dalam keputusan investasi.

Hasil penelitian ini dapat menjadi bahan pertimbangan calon investor dalam mengambil keputusan investasi melalui informasi perusahaan yang disajikan melalui Internet Financial Reporting (IFR). Semakin cepat perusahaan mempublikasikan laporan keuangannya melalui website, dapat mencerminkan kualitas laporan keuangan yang dimiliki sehingga investor dapat menilai perusahaan dari informasi yang tersaji dalam laporan keuangan yang telah dipublikasikan. 
Faktor-faktor yang berpengaruh pada ketepatan waktu Internet Financial Reporting pada perusahaan sektor Pertambangan perlu untuk ditelaah kembali karena hanya profitabilitas perusahaan yang paling menunjukkan kemampuan untuk memengaruhi ketepatan waktu penyampaian laporan keuangan pada publik. Perlu diperhatikan juga faktor-faktor lain yang berpengaruh pada ketepatan waktu Internet Financial Reporting karena dilihat dari kecilnya nilai koefisien determinasi penelitian yang menunjukkan bahwa terdapat faktorfaktor lain yang berpengaruh pada ketepatan waktu Internet Financial Reporting.

\section{SIMPULAN}

Berdasarkan analisis yang dilakukan untuk mengetahui bukti empiris pengaruh leverage, likuiditas, profitabilitas, umur listing, dan reputasi auditor pada Ketepatan Waktu Internet Financial Reporting, maka dapat disimpulkan bahwa Variabel leverage tidak berpengaruh pada probabilitas ketepatan waktu Internet Financial Reporting (IFR) pada perusahaan sektor Pertambangan yang terdaftar di Bursa Efek Indonesia periode 2014 - 2017.

Variabel likuiditas tidak berpengaruh pada probabilitas ketepatan waktu Internet Financial Reporting (IFR) pada perusahaan sektor Pertambangan yang terdaftar di Bursa Efek Indonesia periode 2014 - 2017. Variabel profitabilitas berpengaruh positif dan signifikan pada probabilitas ketepatan waktu Internet Financial Reporting (IFR) pada perusahaan sektor Pertambangan yang terdaftar di Bursa Efek Indonesia periode 2014 - 2017.

Variabel umur listing tidak berpengaruh pada probabilitas ketepatan waktu Internet Financial Reporting (IFR) pada perusahaan sektor Pertambangan yang terdaftar di Bursa Efek Indonesia periode 2014 - 2017, dengan arah penelitian negatif berlawanan dengan hipotesis penelitian. Variabel reputasi auditor tidak berpengaruh pada probabilitas ketepatan waktu Internet Financial Reporting (IFR) pada perusahaan sektor Pertambangan yang terdaftar di Bursa Efek Indonesia periode 2014 - 2017, dengan arah penelitian negatif berlawanan dengan hipotesis penelitian.

Berdasarkan hasil penelitian dan kesimpulan diatas, saran yang dapat diberikan pada penelitian selanjutnya adalah Nilai Nagelkerke R Square yang masih rendah yaitu 11,3\% menunjukan bahwa terdapat variabel-variabel lain yang mempunyai pengaruh pada penelitian yang tidak digunakan pada pengungkapan ketepatan waktu Internet Financial Reporting (pelaporan keuangan melalui website). Penelitian selanjutnya diharapkan malakukan penambahan variabel lain yang lebih tepat sebagai variabel penduga dalam pengungkapan IFR, seperti variabel yang terkait dengan kondisi perekonomian dan kebijakan pemerintah seperti kepemilikan publik, karakteristik keuangan perusahaan, komisaris independen, dan ukuran dewan komisaris.

Penelitian selanjutnya disarankan menggunakan sampel yang lebih banyak dan tahun penelitian yang lebih lama sehingga hasil yang didapat lebih representatif. Penelitian selanjutnya disarankan melakukan penelitian yang melibatkan seluruh sektor baik keuangan maupun non keuangan agar mendapatkan generalisasi simpulan yang lebih baik. Diharapkan Dewan Komisaris perusahaan yang memiliki umur listing yang lama dan tidak tepat 
waktu melakukan Internet Financial Reporting agar mampu mendorong manajemen untuk meningkatkan kualitas Sumber Daya Manusia yang dimiliki.

\section{REFERENSI}

Abdelsalam, O., \& Masry, A. . (2008). The Impact of Board Independence and Ownership Structure on the Timeliness of Corporate Internet Reporting of Irish- Listed Companies. Managerial Finance, 34(12), 907-918.

Agboola, A. A., \& Salawu, M. K. (2012). The Determinants of Internet Financial Reporting: Empirical Evidence from Nigeria. Research Journal of Finance and Accounting, 3(11), 95-106.

Akbar, D. A., \& Daljono. (2014). Analisis Faktor Yang Mempengaruhi Pengungkapan Laporan Keuangan Perusahaan Berbasis Website. Diponegoro Journal of Accounting, 3(3), 1-12.

Akhirra, D. P. (2013). Pengaruh Kinerja Keuangan, Ukuran Bank, Umur Listing, Reputasi Auditor terhadap Internet Financial Reporting pada Perbankan yang Terdaftar di Bursa Efek Indonesia. Jurnal UIN Syarif Hidayatullah, 1(1), $1-20$.

Alali, F., \& Romero, S. (2012). The Use of The Internet for Corporate Reporting In The Mercosur (Southern Common Market): The Argentina Case. Advances in Accounting, 28(1), 157-167.

Alghofur, M. F. (2014). Analisis Pengaruh Ukuran Perusahaan, Leverage, Umur Listing Perusahaan, dan Reputasi Auditor terhadap Penerapan Internet Financial Reporting (IFR). Jurnal Akuntansi Universitas Negeri Hidayatullah Jakarta, 1(1), 1-12.

Almilia, L. (2009). Determining Factors of Internet Financial Reporting in Indonesia. Accounting Taxation, 1(1), 87-99.

Aly, D., Simon, J., \& Hussainey, K. (2010). Determinants of Corporate Internet Reporting: Evidence from Egypt. Managerial Auditing Journal, 25(3), 182-202.

Anggraini, Y. (2012). Analisis Faktor-Faktor Yang Mempengaruhi Pelaporan Keuangan Terhadap Internet (Internet Financial Reporting) dalam Website Perusahaan. Jurnal Akuntansi, 1(1), 1-20.

Anna, Y. D. (2013). Analisis Faktor-Faktor yang Mempengaruhi Internet Corporate Reporting. Sinopsium Nasional Akuntansi XVI Manado. Manado.

Basuony, M. A. K., \& Mohamed, E. K. A. (2014). Determinants of Internet Financial Disclosure in GCC Countries. Asian Journal of Finance $\mathcal{E}$ Accounting, 6(1), 1-12.

Boubaker, S., Lakhal, F., \& Nekhili, M. (2012). The Determinants of Web-based Corporate Reporting in France. Managerial Auditing Journal, 1(2), 126-155.

Debreceny, R., Gray, G., \& Rashman, A. (2002). The Determinants of Internet Financial Reporting. J Account Publik Policy, 1(1), 371-394.

Diatmika, I. G. P. A., \& Yadnyana, I. K. (2017). Pengungkapan Pelaporan Keuangan melalui Website dan Faktor-Faktor yang Memengaruhi. E-Jurnal Akuntansi Universitas Udayana, 21(1), 330-357.

Dolinšek, T., Tominc, P., \& Skerbinjek, A. L. (2014). User's Perceptions on Internet Financial Reporting. Organizacija, 47(4), 254-266.

Goreti, D., \& Lourenço, I. C. (2011). Internet Financial Reporting: Environmental Impact Companies and other Determinants. Enterprise Systems, Accounting 
and Logistics, 1(2), 331-359.

Hanny, S. L., \& Chariri, A. (2012). Analisis Faktor-Faktor Yang Mempengaruhi Internet Financial Reporting Dalam Website Perusahaan. Diponegoro Journal of Accounting, 1(1), 1-3.

Ikhsan, H. N. (2017). Analisis Pengaruh Ukuran Perusahaan, Kepemilikan Publik, dan Umur Listing terhadap Ketepatan Waktu Corporate Internet Reporting pada Perusahaan Perbankan di BEI periode 2014-2016. Jurnal UIN Syarif Hidayatullah, 1(1), 1-20.

Insani, K., \& Agustina, L. (2015). Analisis Rasio Keuangan terhadap Pelaporan Keuangan melalui Internet pada Website Perusahaan. Accounting Analysis Journal, 14(1), 1-20.

Keumala, N. N., \& Muid, D. (2013). Analisis Faktor-Faktor yang Mempengaruhi Pelaporan Keuangan Melalui Website Perusahaan. Diponegoro Journal of Accounting, 2(1), 1-10.

Kusrinanti, M. A. (2012). Pengaruh Karakteristik Keuangan Perusahaan dan Internet Financial Reporting pada Perusahaan yang Terdaftar di Bursa Efek Indonesia. Simposium Nasional Akuntansi XV Banjarmasin. Banjarmasin.

Maharani, R. P. (2017). Faktor-Faktor yang Mempengaruhi Internet Financial Reporting pada Perusahaan Manufaktur yang Terdaftar di Bursa Efek Indonesia. Jurnal Perbanas, 1(1), 12.

Marwati, S. (2016). Analisis Faktor-Faktor Yang Mempengaruhi Pelaporan Keuangan Perusahaan Di Internet (Internet Financial Reporting). Jurnal Universitas Lampung, 1(1), 1-20.

Maryati, E. R. (2014). The Effect of Internet Financial Reporting (IFR) on Firm Value, Stock Price, and Stock Return in The Manufacturing Companies Listed in Indonesia Stock Exchange. The Indonesian Accounting Review, 4(2), $71-80$.

Ojah, K., \& Mokoaleli-Mokoteli, T. (2012). Internet Financial Reporting, Infrastructures and Corporate Governance: An International Analysis. Review of Development Finance, 2(2), 69-83. https://doi.org/dx.doi.org/10.1016/j.rdf.2012.04.001

Oyelere, P., Fawzi, L., \& Fisher, R. (2003). Determinants Of Internet Financial Reporting By New Zealand Companies. Journal of International Financial Management and Accounting, 14(1), 26-63.

Pranata, D., \& Pujiati, D. (2015). The Effect of Liquidity, Profitability, Sales Growth, and Dividend Policy on Stock Prices after The Implementation of IFRS. The Indonesian Accounting Review, 5(2), 169-178.

Prasetya, M., \& Irwandi, S. A. (2016). Faktor-Faktor yang Mempengaruhi Pelaporan Keuangan melalui Internet (Internet Financial Reporting) pada Perusahaan Manufaktur di Bursa Efek Indonesia. The Indonesia Accounting Review, 2(2), 151-158.

Putra, I. G., \& Ramantha, I. W. (2015). Pengaruh Profitabilitas, Umur Perusahaan, Kepemilikan Instituonal, Komisaris Independen, dan Komite Audit Ketepatwaktuan Publikasi Laporan Keuangan Tahunan. E-Jurnal Akuntansi Universitas Udayana, 10(1), 199-213.

Putri, N. W., \& Irwandi, S. A. (2016). The Effect of Firm Size, Financial Performance, Listing Age and Audit Quality on Internet Financial 
Reporting. The Indonesian Accounting Review, 6(2), 239-247.

Rozak, A. (2012). Pengaruh Tingkat Profitabilitas, Ukuran Perusahaan, Kepemilikan Saham oleh Publik, dan Kelompok Industri terhadap Tingkat Internet Finacial Reporting (IFR). Jurnal Computech $\mathcal{E}$ Bisnis, 6(2), 101-112. 